\title{
Performance of a Gasifier Reactor Prototype without a Blower Using Palm Oil Waste
}

\author{
Arief Suardi Nur Chairat ${ }^{1}\left(\right.$, Vendy Antono ${ }^{1, *}$, Prayudi Prayudi ${ }^{1}$, Roswati Nurhasanah ${ }^{1}$ and Hakimul Batih ${ }^{2}$ \\ 1 Department of Mechanical Engineering, Institut Teknologi PLN, Jakarta 11750, Indonesia; \\ arief.suardi@itpln.ac.id (A.S.N.C.); prayudi@itpln.ac.id (P.P.); roswati@itpln.ac.id (R.N.) \\ 2 Indonesian Institute for Energy Economics, Jakarta 12180, Indonesia; hakimulbatih@yahoo.com \\ * Correspondence: vendy@itpln.ac.id
}

Citation: Nur Chairat, A.S.; Antono, V.; Prayudi, P.; Nurhasanah, R.; Batih, H. Performance of a Gasifier Reactor Prototype without a Blower Using Palm Oil Waste. Processes 2021, 9 , 2094. https://doi.org/10.3390/ pr9112094

Academic Editor: Juan Francisco García Martín

Received: 4 October 2021

Accepted: 19 November 2021

Published: 22 November 2021

Publisher's Note: MDPI stays neutral with regard to jurisdictional claims in published maps and institutional affiliations.

Copyright: (c) 2021 by the authors. Licensee MDPI, Basel, Switzerland. This article is an open access article distributed under the terms and conditions of the Creative Commons Attribution (CC BY) license (https:/ / creativecommons.org/licenses/by/ $4.0 /)$.

\begin{abstract}
The usage of palm oil empty fruit bunches (EFBs) in the gasification process adds value to the empty bunches as a renewable energy source. In this study, we design and manufacture a new updraft type of gasifier reactor without a blower so that it does not require electric power in its operation, but uses power from engine suction. Our test results compare the use of biomass waste in conjunction with diesel fuel to run a diesel power plant for $20 \mathrm{~min}$ at a load of 10,000 W: diesel with coconut shell charcoal $(350 \mathrm{~mL})$, diesel with acacia wood charcoal $(380 \mathrm{~mL})$, and diesel with EFB charcoal $(400 \mathrm{~mL})$. The test shows that the highest efficient and the most optimal biomass in the gasification process is coconut shell charcoal, because coconut shell charcoal has a dense structure and, at the time of the experiment, the coconut shell charcoal was filled $15 \mathrm{~cm}$ below the gas outlet pipe hole. From the standpoint of the economic value of the gasifier reactor that is proposed in this study, the result with the lowest cost is that of diesel with EFB charcoal, because, in this experiment, EFBs were the biomass that was not purchased. The additional use of empty fruit bunches of charcoal is able to save $50 \%$ diesel usage.
\end{abstract}

Keywords: updraft gasifier; reactor without a blower; palm oil empty fruit bunches; biomass waste

\section{Introduction}

The issue of global warming that is marked by an increase in temperature and sea levels as well as various natural disasters has become the concern of most countries in the world, and, to curb the rate of global warming, many countries are committed to relinquish the use of fossil energy. In addition, the depletion of fossil fuel supplies, including oil, gas, and coal, has encouraged countries in the world, including Indonesia, to diversify their energy supply, from fossil fuels to renewable energy that is more environmentally friendly [1].

Both in terms of land and the ocean, Indonesia is considered as a big country. It has the second longest coastline in the world after Canada, with a sea area of three quarters of its entire territory area [2]. To provide adequate, equitable, and affordable electrical energy services in Indonesia, it will take a significant amount of and a relatively high technological sophistication as well as a significant development time, owing to the nation's geographical features [3,4]. Based on data from the Ministry of Energy and Mineral Resources, in recent years, the increase in Indonesia's energy consumption has reached 7\% per year [5]. To meet the needs of electricity supply, it is not enough just to rely on fossil energy as the main source. Systematic efforts are needed to develop the potential for new and renewable energy, which is very abundant in Indonesia. The great potential of resources includes geothermal, biomass, coal bed methane (CBM), waterpower, sun, and wind. Electrical energy is a primary concern for the improvement of welfare and national economic growth. Energy sources, such as coal and petroleum, which are used to produce power in Indonesia and whose supply is dwindling, are estimated to run out in the next 30 years [6]. Planned power system designs must consider a variety of factors, including the contamination of the 
environment. An interest in the environment is also essential, because the power sector's dependence on fossil fuels will produce greenhouse gas emissions, and thus renewable energy must be used to reduce greenhouse gas emissions [7]. Ensuring that Indonesians have access to inexpensive, reliable, and high-quality energy is a critical issue for the country's economic development [8]. Promoting the use of biomass resources in producing electricity, especially for rural areas or remote areas that have not yet been electrified, is a real effort to reduce dependence on fossil energy [9]. There are great opportunities for Indonesia to use the potential of renewable energy [10].

One type of plantation commodity that can be used as a source of renewable energy is palm oil waste. Palm oil is an edible oil that is derived from the fleshy mesocarp of the fruit of the oil palm [11]. It plays an essential part in Indonesia's economic activity in terms of its ability to produce a vegetable oil that is much needed by the industrial sector [12]. Oil palm plantations cover 8,774,226 ha in Indonesia, and crude palm oil (CPO) production reached $33,500,691 \mathrm{t}$ in 2016 [13]. Indonesia has 26 provinces where oil palm farms are located. After the fresh fruit is processed into palm oil, approximately 45 percent is discarded as litter, powder, fibers, shells, and empty bunches [14]. The remaining 15 percent is recycled. Approximately 50 percent of the solid waste is comprised of empty bunches [15]. To date, the usage of empty bunches as fuel has been quite limited. From now on, the gasification process will add value to the empty bunches as a renewable energy source.

Fuels, such as biomass and coal, can be converted into combustible gases through gasification, which is a thermal conversion process. These solid carbon fuels are converted to carbon monoxide $(\mathrm{CO})$, hydrogen $\left(\mathrm{H}_{2}\right)$, methane $\left(\mathrm{CH}_{4}\right)$, and carbon dioxide $\left(\mathrm{CO}_{2}\right)$, as well as a small amount of hydrocarbons, such as ethane and propylene (known as syngas) [16,17]. In general, the gasification process involves the reaction of carbon with air, oxygen, steam, carbon dioxide, or a mixture of these gases at temperatures of $1300^{\circ} \mathrm{F}$ or more, to produce a gaseous product that can be used for electric power, as a heat source, or feedstock for the synthesis of chemicals, liquid fuels, or other gaseous fuels (such as hydrogen) $[18,19]$. Furthermore, recent research has shown that the temperature conditions in the gasification process are also influenced by biomass particle size and gas-carrying capacity [20].

During the gasification process, four different thermal and chemical events, including combustion, oxidation, pyrolysis, and drying, take place in a gasifier. Tar, nitrogen, and sulfur are among the contaminants in the gasification process's output $\left(\mathrm{H}_{2} \mathrm{~S}, \mathrm{COS}\right)[17,21]$. The choice of reactor type is one way to limit the amount of tar in the gasification process [15]. By adopting this populist-based palm oil biomass gasifier reactor model, not only major businesses, but also ordinary people, would gain from the benefits of the electricity.

Many studies have been conducted to create palm oil waste gasifier reactors and power plants. Using the same specifications as the intermediate design, Pratoto (2010) developed a gasifier furnace for updraft-type empty bunches, taking into account the heating value of biomass fuel, the energy required for various uses, and the furnace's operating time [22]. Using a modified updraft gasification system, Rinovianto (2012) intended to lower the tar content of the combustible gas by separating its output into two zones, one above and one below the gasifier [23]. Using empty bunches as an energy source, Sanjaya (2018) proposed a downdraft-type gasification process with a gasification output power of $50.96 \mathrm{kWh}$ [24].

Several investigations have shown that a gasifier without a blower that relies on engine suction force to operate has not yet been designed and built. To achieve an energy-efficient power plant unit by utilizing local biomass (palm oil residues/solid waste) and electrical circumstances in Indonesia, we design a gasifier without a blower using palm oil waste. Fuel oil as a fuel source for power plants will be substituted for syngas produced from solid waste using a gasifier. Using a gasifier reactor technology that does not require a blower to perform, the gasifier reactor does not require electric power. 


\section{Reactor Prototype Design}

The construction of the gasifier reactor prototype is a relatively crucial research stage and can be completed in a well-equipped workshop using assembly techniques for metallic materials and basic welding. The purpose of making this prototype is to test the performance of a gasifier without a blower, which is implemented in a biomass power plant using empty fruit bunches as fuel to produce syngas.

Prototyping a gasifier has as its goal the creation of a real solution model for the problem that has been defined and discussed during the concept/idea stage of the project [25]. It is an updraft gasifier, which is one of the oldest and simplest gasifiers designs available to date (Figure 1). As the gasification medium (air, oxygen, or steam) moves upwards, the fuel layer moves downwards, and the gases and solid products move in opposite directions because of this arrangement.

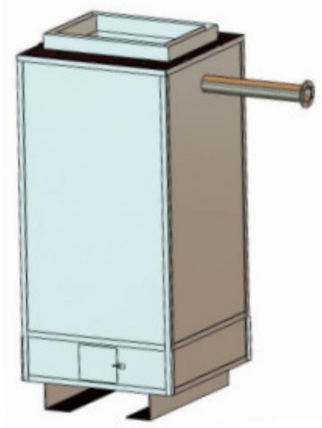

Figure 1. A 3D design of the gasifier reactor without a blower.

Keeping the gasification system's pressure drop as small as possible is critical when building a gasifier prototype. Gasifiers, cyclone separators, and gas repair systems have a pressure drop that cannot be avoided, so large pipes are required (Figure 2). Pressure drop is depicted in many handbooks as a result of standard pipelines, and pipe fittings, such as elbows and couplings, also lower the pressure in the system. However, the pipeline's gas flow rate must be sufficient to transport the dissolved solids to the proper discharge point, as shown in the figure below, rather than storing them in the pipeline as previously stated.
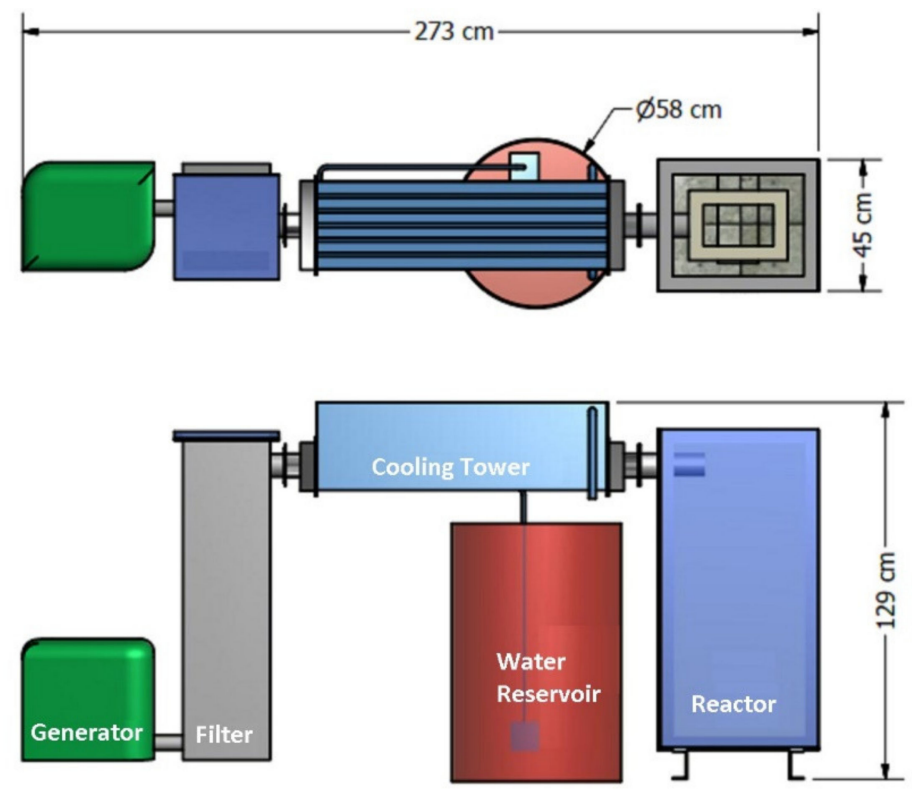

Figure 2. A 3D design of the power plant with palm oil empty fruit bunch as fuel to produce syngas. 


\subsection{Rate of Fuel Consumption}

According to the stages of the research plan, a gasifier without a blower produces an output power $\left(P_{0}\right)$ of $5 \mathrm{~kW}$. In Sanjaya's study (2018), the High Heating Value $(H H V)$ is $15.22 \mathrm{MJ} / \mathrm{kg}$ and the gasification efficiency $(\eta)$ is $48.22 \%$. Based on these values, we can obtain the value of the supply of energy needs by using the equation:

$$
\text { Fuel Consumption Rate }=\frac{P_{0} \times 3.6}{H H V \times \eta}
$$

\subsection{Reactor Dimension}

The main dimension of the updraft type gasifier furnace is the gasification reactor tube. The technical specifications presented in the previous section are used to determine the dimensions and height of the updraft-type gasification reactor. The cross-section of the reactor can be obtained with various geometries. In general, a cylindrical cross section is widely used, but, in this study, we tried to make a gasifier with a rectangular cross section. The larger the diameter $(D)$, the greater the power output. The cross-sectional dimensions of the furnace reactor are determined using the following equation:

$$
D=\sqrt{\frac{1.27 \times F C R}{\text { Specific Gasification Rate }}}
$$

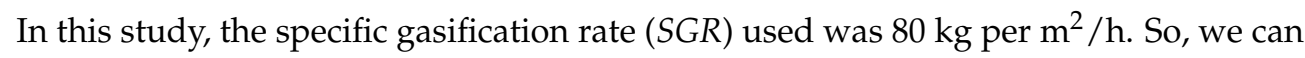
find the cross-sectional area of the reactor with the following equation:

$$
A=\pi r^{2}
$$

In addition to the cross-sectional area, it is also necessary to find the height of the reactor $(h)$, fuel density $(\rho)$, and gasifier operating time $(t)$ using the following equation:

$$
h=\frac{t \times S G R}{\rho}
$$

\subsection{Reactor Materials}

Gasifiers are manufactured using commercially available materials, such as steel pipes, sheets, and plates. During the material selection process, one should (if possible) select materials that are readily available and use the tools available in large quantities. Prototyping gasifiers should avoid exotic alloys, complex special shapes, and special fabrication techniques that require large initial setup and tooling costs, unless the reasons for their use are justifiable. The tools and materials used in the literature to make a set of gasifier reactor without a blower include refractory cement, fire cement needle, refractory brick, an angle iron of $6 \times 6 \mathrm{~cm}^{2}$, a $4 \times 4$ elbow iron, a $1 \mathrm{~mm}$ thick stainless-steel plate, a stainless steel seamless pipe of $14 \mathrm{~mm}$ and thickness of $1 \mathrm{~mm}$, a stainless steel seamless pipe of $25 \mathrm{~mm}$ and thickness of $2 \mathrm{~mm}$, a pipe ss od $50 \mathrm{~mm}$, a brass stopper of 2 inches, and glass wool of $2.5 \mathrm{~cm}$ of thickness.

\subsection{Prototype Performance Test}

There is no design process without testing and verification. The gasifier prototype testing phase is carried out to see if the design parameters are suitable for the built product and to pay attention to the gasifier reactor's performance in a biomass power plant. Different kinds of biomass were examined in the process of identifying the basic biomass fuel for gasifier design tools, including woody biomass (acacia wood), and coconut shell is one type of biomass that has the tendency to create energy. Coconut shell charcoal can be made by pyrolyzing coconuts into heat. Waste from oil palm plantations in Indonesia is called oil palm fruit empty bunches (FEBs). Many studies have been conducted to turn this waste into a significant economic product, one of which is attempting to turn it into charcoal for 
use in gasifiers. Experiments used buckets filled with water up to the water heater's level and then added ten units of $1 \mathrm{~kW}$ water heater loads to see how long it would take to reach the boiling point.

\section{Test Results and Discussion}

Each side of the reactor is $15 \mathrm{~cm}$ thick, and the reactor's height is $110 \mathrm{~cm}$. The goal of this design is to help electrify low- and moderate-income neighborhoods that are particularly vulnerable to natural disasters. The prototype is a stainless steel part in the form of rectangles and squares that are later mixed into one tool; the reactor serves as a place to convert solid fuel into gas while also keeping the gas free of hazardous substances. Gasifiers are devices or reactors that use gasification technics or the operation of using heat to produce solid biomass or other carbonaceous solids into gas. The reactor can be used for as much as $15 \mathrm{~kg}$ of charcoal. In the first stage of testing, we tried to use $12 \mathrm{~kg}$ of charcoal and we operated it for $3 \mathrm{~h}$ by connecting 20 units of incandescent lamps, each with a capacity of $50 \mathrm{~W}$ (Figures 3 and 4 ).

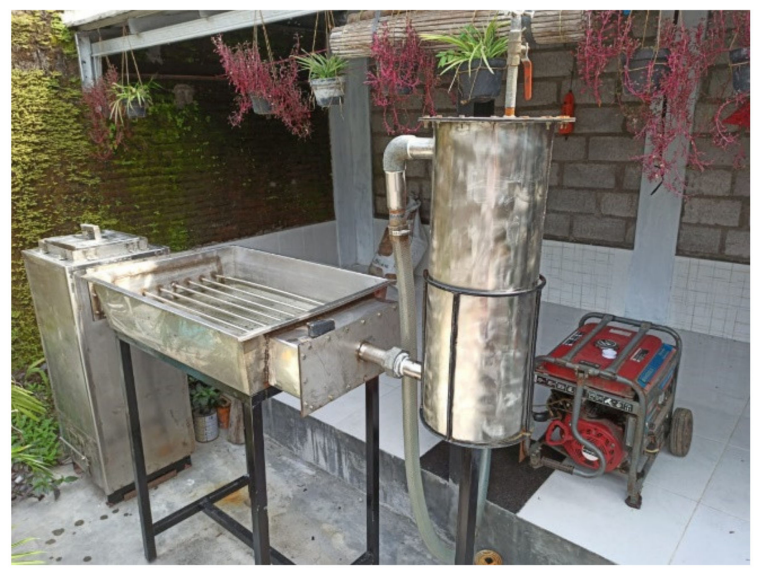

Figure 3. The experiment setup of biomass power plant with the generator set used in the testing process is the Yamakoyo GFH 4500.

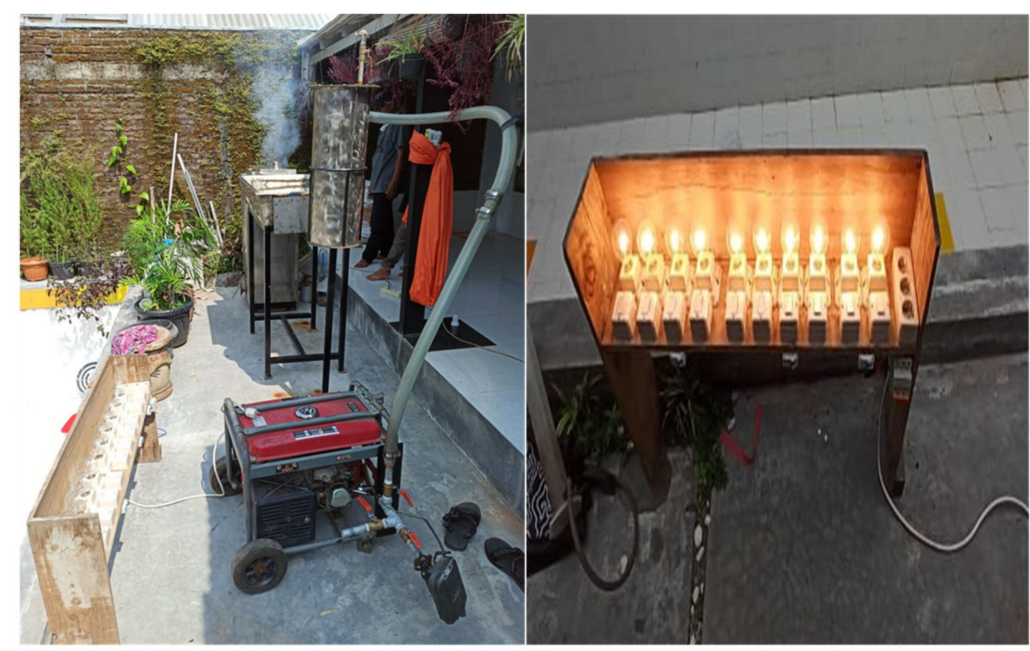

Figure 4. The test is carried out directly by utilizing syngas to operate a generator that is loaded with 20 incandescent light bulbs with a capacity of $50 \mathrm{~W}$ each.

However, a tool to measure power output was not used during testing because the focus at this stage of development was on the design of the gasifier reactor for palm oil waste biomass. In order to determine the specific values of the power generated, systematic measurements must be performed at an advanced stage. Nevertheless, the test results 
demonstrated, even visually, that the gasifier and generator combination can operate with a load of 20 incandescent lamps.

The gasifier reactor operates by introducing filling material in the form of biomass, such as wood charcoal, coconut shell charcoal, and EFBs, up to $20 \mathrm{~cm}$ below the gas pipe hole connected to the cooler. Biomass is first charred until it is ready to join the gasifier reactor for the gasification process. The charcoal is heated first through manual combustion and incrementally inserting it through the top half hole; after the charcoal burning process takes place, adequate biomass is used to maintain adequate combustion.

According to the experiment's findings, the most efficient way to use biomass is to combine solar biomass with coconut shell charcoal. The calorific value of the coconut shell charcoal itself is a determining factor, as the more energy is produced, the higher the calorific value. Table 1 compares the efficiency of all fuels, while Table 2 and Figure 5 show the comparison of calorific value and temperature profile for all fuel types used in the gasification process. The coconut shell takes about $5-6 \mathrm{~h}$ in the pyrolysis process to convert biomass into fuel for this gasification process, while EFB takes about 6-8 $\mathrm{h}$ longer than the coconut shell pyrolysis process because the weather during the drying process of the oil palm reservoir is not optimal, so there is still water content. Tests are conducted on the diesel engine without a load to ensure gasifier reactor performance, and the efficiency of using diesel fuel is seen. Coconut shell charcoal proved to be more cost-effective in experiments lasting $20 \mathrm{~min}$.

Table 1. Comparison of various biomass waste fuel efficiency.

\begin{tabular}{ccccc}
\hline \multirow{2}{*}{ Fuel Type } & \multicolumn{2}{c}{ Testing without Load } & \multicolumn{2}{c}{ Testing with Load } \\
\cline { 2 - 5 } & $\begin{array}{c}\text { Fuel Consumption } \\
(\mathbf{m L})\end{array}$ & $\begin{array}{c}\text { Biomass Used } \\
(\mathbf{k g})\end{array}$ & $\begin{array}{c}\text { Fuel Consumption } \\
(\mathbf{m L})\end{array}$ & $\begin{array}{c}\text { Biomass Used } \\
(\mathbf{k g})\end{array}$ \\
\hline Diesel & 350 & 0 & 800 & 0 \\
\hline Diesel + acacia wood charcoal & 220 & 2.8 & 380 & 2.8 \\
\hline Diesel + coconut shell charcoal & 200 & 3 & 350 & 3 \\
\hline Diesel + EFB charcoal & 280 & 2 & 400 & 2 \\
\hline
\end{tabular}

Table 2. Comparison of calorific value and temperature.

\begin{tabular}{ccc}
\hline Type of Fuel and Biomass & $\begin{array}{c}\text { Calorific Value } \\
\text { (kcal/kg) }\end{array}$ & $\begin{array}{c}\text { Temperature } \\
\text { ( } \mathbf{C} \text { ) }\end{array}$ \\
\hline Diesel & 8591 & - \\
\hline Acacia wood charcoal & 4800 & 754.2 \\
\hline Coconut shell charcoal & 5700 & 1206 \\
\hline EFB charcoal & 3353 & 1166 \\
\hline
\end{tabular}

Before opening the valve to the diesel engine, the temperature of the combustion chamber was measured to see how well it performed. Because the charcoal is not completely dry when it goes into the reactor, the structure of the charcoal varies from bunch to bunch, resulting in a wide range of temperatures. Because coconut shell charcoal has a dense structure and was filled $15 \mathrm{~cm}$ below the gas outlet pipe hole during the experiment, coconut shell charcoal was found to be the most efficient combustion process for burning coconut shell oil. Table 1 shows the most efficient combinations of densities and amounts of incoming charcoal that combust $15 \mathrm{~cm}$ below the outlet pipe hole. The Castable TNC 17 type fire cement material can withstand temperatures of up to $1206^{\circ} \mathrm{C}$, according to this heat measurement. 


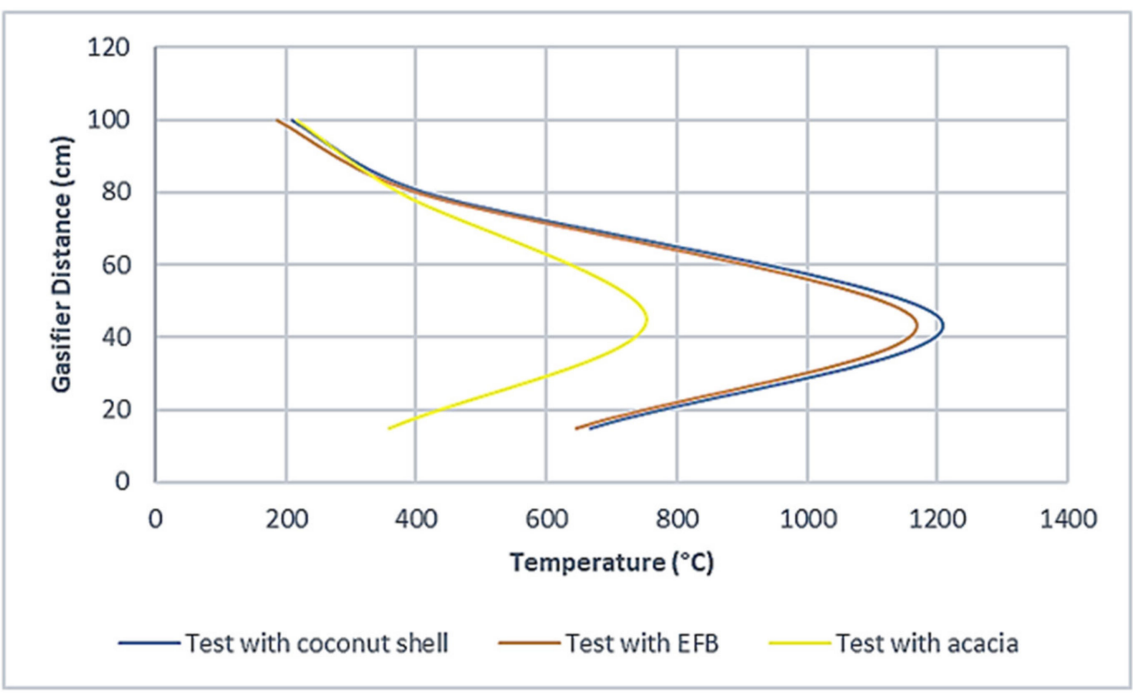

Figure 5. Temperature profile for all tests.

Table 3 shows the comparison of the value of fuel consumption cost with the use of diesel and a mixture of diesel and biomass. The current condition is that people in the project location still use diesel fuel generators to obtain electricity. The calculation of the costs required when operating with and without the load results in the composition of diesel and EFB being the cheapest alternative compared to other types of biomass composition and also cheaper than the use of solar fuel. This is because empty fruit bunches can be obtained directly, without having to be bought, from community-owned oil palm plantations during the harvest period. Thus, the gasifier reactor developed is suitable for use in remote rural areas that have oil palm plantations. The types of acacia wood and coconut shell biomass are not directly available at the project site, so it requires a high cost to obtain them. In other areas where there are various types of biomasses available, the fuel consumption costs may have different values.

Table 3. Comparison of fuel consumption cost.

\begin{tabular}{ccc}
\hline \multirow{2}{*}{ Fuel Type } & Testing without Load & Testing with Load \\
\cline { 2 - 3 } & Cost of Consumption (Rp) & Cost of Consumption (Rp) \\
\hline Diesel & 3290 & 7520 \\
\hline Diesel + acacia wood & 16,068 & 17,572 \\
\hline Diesel + coconut shell & 22,880 & 24,290 \\
\hline Diesel + EFB & 2632 & 3760 \\
\hline
\end{tabular}

\section{Conclusions}

A gasifier reactor was designed, developed, and tested with the goal of achieving a simple biomass gasifier in the producer gas. The experiment results show that the use of solar biomass combined with coconut shell charcoal has the highest efficiency of biomass use. Coconut shell charcoal has the best combustion characteristics because of its dense structure, and towards the stage of the experiment, coconut shell charcoal was filled $15 \mathrm{~cm}$ below the gas outlet pipe hole. The cheapest possible finding from the economic value of the gasifier reactor that has been produced is diesel with EFB charcoal, because, in this experiment, EFB is the biomass that can be obtained directly without having to buy. The additional use of empty bunches of charcoal can save up to $50 \%$ on diesel consumption. This study can answer various energy and environmental problems faced today by collecting and utilizing various simple and inexpensive technologies that are feasible to be managed by the public. In order to produce lower tar levels in the future, the performance of the 
gasifier must be tested. Some recommendations for testing the next stage include using a larger capacity generator and the avoidance, at a later stage, of the moisture in the filter component from wet charcoal entering the channel

Author Contributions: Conceptualization, V.A.; methodology, V.A.; formal analysis, H.B.; investigation, V.A.; data curation, R.N.; writing-original draft preparation, A.S.N.C.; writing-review and editing, A.S.N.C. and R.N.; supervision, P.P. and H.B.; project administration, H.B.; funding acquisition, A.S.N.C. All authors have read and agreed to the published version of the manuscript.

Funding: The research for this article was funded by the Institut Teknologi PLN research and innovation program in 2020.

Acknowledgments: This paper and the research behind it would not have been possible without the exceptional support of Kepurun Panawa Indonesia that provided testing facilities, my university, and my colleagues at Insitut Teknologi PLN. I am also grateful for the insightful comments offered by the anonymous peer reviewers.

Conflicts of Interest: Neither the authors nor the contributors have any financial or non-financial relationships with or involvement in any organization with a financial interest (such as honoraria; grants for education; participation in speakers' bureaus; membership; employment; consulting; stock ownership or other equity interest; and expert testimony or patent-licensing arrangements) in the subject-matter or material covered by this paper.

\section{Nomenclature}

$\begin{array}{ll}\text { FCR } & \text { Fuel Consumption Rate }(\mathrm{kg} / \mathrm{h}) \\ \text { HHV } & \text { High Heating Value }(\mathrm{MJ} / \mathrm{kg}) \\ \text { SGR } & \text { Specific Gasification Rate }\left(\mathrm{kg} / \mathrm{m}^{2} / \mathrm{h}\right) \\ P_{0} & \text { Output }(\mathrm{kWh}) \\ \eta & \text { Efficiency }(\%) \\ D & \text { Reactor Diameter }(\mathrm{m}) \\ A & \text { Cross-sectional area }\left(\mathrm{cm}^{2}\right) \\ r & \text { Radius }(\mathrm{cm}) \\ h & \text { Reactor height }(\mathrm{m}) \\ t & \text { Operational time }(\mathrm{h}) \\ \rho & \text { Fuel density }\left(\mathrm{kg} / \mathrm{m}^{3}\right)\end{array}$

\section{References}

1. Wu, T.; Xu, D.L.; Yang, J.B. Multiple criteria performance modelling and impact assessment of renewable Energy systems-A literature review. In Renewable Energies Business Outlook 2050; Springer: Berlin/Heridelberg, Germany, 2018; pp. 1-15. [CrossRef]

2. Susandi, A. The Changing of the Electric and Non Electric Energy Production and Technology Options for Emission Abatement on Indonesia. Available online: https: / / iteseerx.ist.psu.edu/viewdoc/download?doi=10.1.1.201.5771\&rep=rep1\&type=pdf (accessed on 17 November 2021).

3. Kunaifi, K.; Veldhuis, A.J.; Reinders, A.H.M.E. The Electricity Grid in Indonesia: The Experiences of End-Users and Their Attitudes toward Solar Photovoltaics; Springer Nature: Cham, Switzerland, 2020.

4. Yurnaidi, Z. Opportunities and Challenges of Renewable Energy and Distributed Generation Promotion for Rural Electrification in Indonesia. Green Energy Technol. 2010, 44, 102-107. [CrossRef]

5. Kementerian ESDM. Jurnal Energi. 2016. Available online: https://www.esdm.go.id/assets/media/content/FIX2_Jurnal_ Energi_Edisi_2_17112016(1).pdf (accessed on 17 November 2021).

6. Van den Bergh, K.; Delarue, E. Quantifying $\mathrm{CO}_{2}$ abatement costs in the power sector. Energy Policy 2015, 80, 88-97. [CrossRef]

7. Xiong, W.; Yang, Y.; Wang, Y.; Zhang, X. Marginal abatement cost curve for wind power in China: A provincial-level analysis. Energy Sci. Eng. 2016, 4, 245-255. [CrossRef]

8. ESCAP. Energy Transition Pathways for the 2030 Agenda SDG7 Roadmap for Indonesia. 2020. Available online: https://www. unescap.org/resources/energy-transition-pathways-2030-agenda-sdg7-roadmap-indonesia (accessed on 17 November 2021).

9. Veldhuis, A.J.; Reinders, A.H.M.E. Reviewing the potential and cost-effectiveness of off-grid PV systems in Indonesia on a provincial level. Renew. Sustain. Energy Rev. 2015, 52, 757-769. [CrossRef]

10. Pacesila, M.; Burcea, S.G.; Colesca, S.E. Analysis of renewable energies in European Union. Renew. Sustain. Energy Rev. 2016, 56, 156-170. [CrossRef]

11. Papilo, P.; Marimin; Hambali, E.; Sitanggang, I.S. Sustainability index assessment of palm oil-based bioenergy in Indonesia. J. Clean. Prod. 2018, 196, 808-820. [CrossRef] 
12. Yatim, P.; Ngan, S.L.; Lam, H.L. Sustainable Supply Chain: Feedstock Logistics Issues of Palm Oil Biomass Industry in Malaysia. In Transition towards 100\% Renewable Energy; Springer: Cham, Switzerland, 2018; pp. 467-479. [CrossRef]

13. Secretariat General National Energy Council. Indonesia Energy Outlook (IEO) 2019. 2019. Available online: https: / / www.esdm. go.id/assets/media/content/content-indonesia-energy-outlook-2019-english-version.pdf (accessed on 17 November 2021).

14. Khatun, R.; Reza, M.I.H.; Moniruzzaman, M.; Yaakob, Z. Sustainable oil palm industry: The possibilities. Renew. Sustain. Energy Rev. 2017, 76, 608-619. [CrossRef]

15. Effendi, S.; Azharuddin; Pramedian, G. Rancang Bangun Alat Gasifikasi Sistem Updraft Double Gas Outlet Berbahan bakar Biomassa (Tempurung Kelapa) dengan Pengaruh Laju Air Udara Pembakaran Terhadap Produk Syngas. J. Austenit. 2013, 5, 15-21.

16. Selvakkumaran, S.; Limmeechokchai, B. Assessment of long-term low emission power generation in Sri Lanka and Thailand. Sustain. Energy Technol. Assess. 2017, 21, 121-141. [CrossRef]

17. Basu, P. Biomass Gasification and Pyrolysis: Practical Design and Theory; Academic Press: Cambridge, MA, USA, 2013.

18. Chand Malav, L.; Yadav, K.K.; Gupta, N.; Kumar, S.; Sharma, G.K.; Krishnan, S.; Rezania, S.; Kamyab, H.; Pham, Q.B.; Yadav, S.; et al. A review on municipal solid waste as a renewable source for waste-to-energy project in India: Current practices, challenges, and future opportunities. J. Clean. Prod. 2020, 277, 123227. [CrossRef]

19. Perea-Moreno, M.A.; Samerón-Manzano, E.; Perea-Moreno, A.J. Biomass as renewable energy: Worldwide research trends. Sustainability 2019, 11, 863. [CrossRef]

20. Jia, Y.; Wang, Y.; Zhang, Q.; Rong, H.; Liu, Y.; Xiao, B.; Guo, D.; Laghari, M.; Ruan, R. Gas-carrying enhances the combustion temperature of the biomass particles. Energy 2022, 239, 121956. [CrossRef]

21. Pratiwi, I.; Studi, P.; Analisis, T.; Migas, L.; Akamigas, P. Rancang bangun alat gasifikasi biomassa (kayu karet) sistem updraft single gas outlet design of biomass gasification equipment (rubber wood) updraft single gas outlet system. J. Tek. Patra Akad. 2020, 11, 38-49.

22. Pratoto, A.; Sutanto, A.; Praja, E.H.; Armenda, D. Rancang Bangun Tungku Gasifier Untuk Pemanfaatan Tandan Kelapa Sawit Sebagai Sumber Eenergi. In Proceedings of the Seminar Nasional Tahunan Teknik Mesin (SNTTM) ke-9, Palembang, Indonesia, 13-15 October 2010; pp. 13-15.

23. Rinovianto, G. Karakteristik Gasifikasi Pada Updraft Double Gas Outlet; Universitas Indonesia: Kota Depok, Indonesia, 2012.

24. Sanjaya, D.; Notosudjono, D.; Fiddiansyah, D.B. Perencanaan Gasifikasi Dari Limbah Kelapa Sawit Sebagai Energi Alternatif Di Ptpn Viii Cikasungka Kabupaten Bogor. Available online: http://jom.unpak.ac.id/index.php/teknikelektro/article/view/9771 (accessed on 17 November 2021).

25. Siregar, K. Rancang Bangun Gasifier Downdraft dan Aplikasi PLT-Biomassa Kapasitas 50 kW Untuk Daerah Terisolasi Dari Jaringan Listrik PLN. In Proceedings of the Seminar Nasional Perteta-HIPI 2014, Online. 11-12 November 2014. 